\title{
Generation Y's Employment Motivations and Attitudes
}

\author{
Ms. Priyanka.R.Patel* \\ Asst. Professor with the Institute of Language Studies and Applied Social Sciences (ILSASS), Vallabh \\ Vidyanagar Anand - 388120.
}

\begin{abstract}
Researchers, supervisors, and human resource professionals have long struggled with perfecting management strategies for employees. The three most prevalent working generations currently are Baby Boomers, Generation X, and Generation Y. To understand Generation Y's employment motivations and attitudes, two ideas must be discussed: (a) a working definition of generation, and (b) an understanding of preceding generations' motivations and attitudes. This paper throws light on measures that should be taken to retain and motivate Generation Y employees and how are they important in near future.
\end{abstract}

Key words: Generation Y, motivate, retain, development, stability, Management Style

\section{Introduction}

Generation Y's transition from college and grad school into the working world has been a bumpy one, to put it politely. "Extended adolescence" is real, "helicopter parents" are real, and organizations that hire twentysomething's are finding that many of them don't walk and talk and act like adults. Making them fit for the professional where older and wiser managers are struggling to find the best ways to recruit, manage, "professionalize," groom, and retain Gen Y.

Whatever kind of business or organization you run, 100-million strong Generation $\mathrm{Y}$ is going to be at the heart of your success or failure, so you have no choice but to figure out what makes them tick. You won't be able to "hire around" the quirks of your next generation of employees and future leaders.

When defining generations a number of factors are taken into consideration, including birth rates, significant world events and shared life experiences[1]. Employers need to acknowledge generational differences when creating a working environment which is both productive and motivational. Currently workforce consist of Baby Boomers, Generation X and Y and the i Generation. As the Lucky Generation moves into retirement and Baby Boomers become more family orientated, it is becoming increasingly important for employers to understand future generations, like Generation Y. They will, after all, be the bosses of tomorrow.

\section{Who is Gen Y?}

Generation Y (Gen Y) consists of those born between 1980-1994, who make up a whooping 20.5\% of the population[2]. Born in the age of the internet, Gen Y is not only the one of the youngest generations in the workplace but also the most technologically advanced. Social networking technology (like Facebook) and increased importance of travel, has helped Gen Y to see the world as a global community. In this sense, this younger generation is better suited to global climate of the modern workplace. Despite the introduction of Higher Education Contribution Scheme (HECS), Gen Y has propelled a great increase in tertiary education with one in four having a Bachelor Degree and above in 2006[3]. The great potential of this highly qualified group is curbed by a perception of a short attention span and a need for instant gratification.

\section{Motivating Generation Y}

Gen Y has a reputation for shorter tenure in jobs with one in four 20-24 year olds changing careers every year. It is an employees market making it crucial for employers to learn how to motivate and therefore retain staff. Various social research has highlighted the most significant ways in which employers can mobilize their employees for optimum results.

\section{- Management Style}

Gen Y grew up in the period where society reared their children with great self esteem and and self worth. This confidence needs to be coddled and managers must be enthusiastic and encouraging through public affirmation. An interactive style of management in which bosses highlight areas for improvement and guide towards achievement is key. It is important to be accessible and explain to staff not only why but how decisions are made. Management must be participatory and inclusive which can be achieved through constant staff feedback via surveys, focus groups and exit interviews with departing staff. 


\section{- Training and career development}

Employers must support development or Gen $\mathrm{Y}$ has a tendency to feel stagnant and lose interest in their careers. Gen Y does not fear commitment but rather yearns for new challenges through variety and change. This can be achieved through ongoing education and career development in which staff learn not only technical skills but have a chance to be mentored or coached individually. The multitasking nature of Gen Y means that junior staff can handle greater responsibilities than traditionally thought and thrive working on several projects at once. Contrary to previous generations, Gen Y expect promotions much earlier in their career so constant evaluation of skills and development can help create more company loyalty.

\section{- Workplace culture}

Creating the right workplace culture can spark a passion within employees that resonates in their work. While the Baby Boomers and Gen X struggled with the work/family balance, Gen Y is more focused on being part of a career which is meaningful. Many factors, like friendship, are important factors when Gen Y settles into their career. Lines between social interaction and work life no longer exist for this generation and building staff relationships through events and team building is essential. A lifestyle friendly environment is important and including elements like child care and family friendly functions can help to engage Gen Y. A diverse workforce is suited to Gen Y who embraces multi-generations, genders and cultures. This technologically advanced generation also requires an office which is equipped with modern facilities and progressive technology.

Strategic changes can help to motivate Gen $\mathrm{Y}$ and in turn create a workforce more capable than perhaps any before.

\section{- Making expectations clear}

Talented individuals get frustrated when they feel they aren't getting anything done. That's why unclear expectations and ambiguous directives are a recipe for burnout and resignations. For Generation Y, accomplishments are the steppingstones to success. Without a sense of accomplishment and forward momentum, Gen-Yers feel as though they're spinning their wheels.

\section{-Develop and coach}

Generation Y employees view their jobs as a continuation of their educations. They need to feel they are learning, and they especially appreciate being coached. That means you have to actually be competent in coaching techniques. Otherwise, your concern for your young talent's development might not seem authentic. How you listen, question, speak, and give feedback are essential to keeping your Gen-Y staff engaged and motivated.

Stretch the comfort zones

Generation Y people welcome new challenges and a manageable degree of risk. This is an adrenaline-driven generation that craves change and challenge, and members won't shrink from assignments outside their comfort zones. They see an opportunity to take on a new challenge as a vote of confidence in their abilities.

\section{-Promote team cohesiveness}

Team loyalty is a key tool for motivating and retaining Generation Y members. They identify strongly with their team, often more strongly than they identify with their company. The team is a source of social and professional support and gives them a base from which they can move forward. You need to enhance their collective culture, their sense of team, and their feeling of cohesion and social integration.

\section{-Encourage career planning--even outside your company}

Generation Y members insist on growth and mobility. Keep them up to date about growth opportunities at your company, and work with them to understand their interests and set a timeline for greater responsibility. If you aren't able to give them the opportunities they want, it's important not to stymie their job hunts elsewhere. If your Gen-Y employees need to leave your company to grow professionally, don't make them feel disloyal.

Generation Y people don't expect or even desire lifetime employment at any one place. They do value knowing that as they move ahead, you will be there for them. The more they feel that you are a true partner in their career, the more likely they are to stay and fully contribute to your start-up.

\section{Conclusion}

It is concluded that Generation Y employees need to be tackled differently then baby boomers generation the approach towards them must be more versatile rather than static one they would be no longer bound with the sets of rules and regulations , money is not only the one motivating factor for them what they need is autonomy ,feedback, development, change, good working environment and they want to enhance in 
career so the mangers should keep following things in mind while recruiting employees of generation $\mathrm{Y}$ who are going to be the future leaders as well as managers

\section{References}

[1]. Alch, M. (2000). Get ready for the Net Generation. Training and Development, 54(2), 32-34.Barr, S. (2007, September 24). Bringing Generation $\mathrm{Y}$ into the fold. Washington Post.Retrieved from http://www.washingtonpost.com/wpdyn/content/article/2007/09/23/

[2]. AR2007092301072.html

[3]. Broadbridge, A. M, Maxwell, G. A., \& Ogden, S. M. (2007). Experiences, perceptions, and expectations of retail employment for Generation Y. Career Development International,12(6), 523-544.

[4]. Cennamo, L., \& Gardner, D. (2008). Generational differences in work values, outcomes and person-organisation values fit. Journal of Managerial Psychology, 23(8), 891-906.

[5]. Clark, A. D. (2007, Fall). The new reality: Using benefits to attract and retain talent.

[6]. Employment Relations Today, 47-53.

[7]. Crumpacker, M., \& Crumpacker, J. D. (2007). Succession planning and generational stereotypes: Should HR consider age-based values and attitudes a relevant factor or a passing fad? Public Personnel Management, 36(4), 349-69.

[8]. Dries, N., Pepermans, R., \& DeKerpel, E. (2008). Exploring four generations' beliefs about career: Is 'satisfied' the new 'successful'? Journal of Management Psychology, 23(8),907-928.

[9]. Egri, C. P., \& Ralston, D. A. (2004). Generation cohorts and personal values: A comparison of China and the United States. Organization Science, 15(2), 210-220.

[10]. Essinger, C. (2006, Fall). Managing the millennial generation. Texas Library Journal, 82(3),104-107.

[11]. Freifield, I. (2007). Are you ready for us? Training, 44(6), 8. Hess, N., \& Jepsen, D. M. (2009). Career stage and generational differences in psychological contracts. Career Development International, 14(3), 261-283.

[12]. Hira, N. A. (2007, May 15). Attracting the twentysomething worker. Fortune Magazine. Retrieved from http://money.cnn.com/magazines/fortune/fortune_archive/2007/05/28/100033934/

[13]. Holden, R., \& Harte, V. (2004). New graduate engagement with 'professional development'.Journal of European Industrial Training, 28(2/3/4), 272-282.

[14]. Howe, N., \& Strauss, B. (2000). Millennials rising: The next greatest generation. New York:Vintage Books.

[15]. Hubbard, J., \& Singh, P. (2009). The evolution of employee benefits at the economical insurance group. Compensation and Benefits Review, 41(6), 27-35.

[16]. Kim, H., Knight, D. K., \& Crutsinger, C. (2009). Generation Y employees' retail work experience:The mediating effect of job characteristics. Journal of Business Research, 62, 548-556.

[17]. King, Z. (2003). New or traditional careers? A study of UK graduates' preferences. Human Resource Management Journal, 13(1), $5-26$.

[18]. Kofman, B., \& Eckler, K. (2005). They are your future: Attracting and retaining Generation Y. Canadian Human Resource Reporter, 18(8), 7.

[19]. Kupperschmidt, B. (2000). Multigeneration employees: Strategies for effective management.

[20]. Mc Crindle Research,ABS, Gov., 2007 census 